\title{
2021: a new turn for JCCS
}

\author{
Bernard Perbal ${ }^{1}$ (1)
}

Received: 2 January 2021 / Accepted: 4 January 2021 / Published online: 4 February 2021

(c) The International CCN Society 2021

Dear Colleagues and Readers,

At the dawn of the new year 2021, I am pleased to announce that we have now undertaken the first step in the proposed renewal of the Journal of Cell Communication and Signaling (JCCS) that I presented at the Niagara Workshop on the CCN family of genes (Leask and Perbal 2020, Perbal 2020b).

Professor Andrew Leask who accepted my invitation to become the Editor in Chief of JCCS, will take up his new position, effective January 1, 2021.

Let me review a few milestones in the saga of JCCS.

\section{Inception and growth of JCCS}

At the turn of the twenty-first century, work carried out on regulatory factors which are currently officially referred to by the CCN acronym (Perbal et al. 2018), pointed to them as critical players in the control of intercellular communication and the integration of signals from the surrounding environment. At the time when a founding member of the CCN family of proteins had been discovered by my laboratory (Joliot et al. 1992), publications addressing intercellular signaling and cross-signaling of cells with their microenvironment were scattered in various journals dealing with transduction signals or more general biological aspects. To fill this gap, I proposed to BioMedCentral to create a journal that I designated «Cell Communication and Signaling», in which I presented my views on the need for such a publication (Perbal 2003).

The significant increase in the publication charge to be paid by the authors, following the commercial modifications proposed by BMC in 2006, did not correspond to our wish to

Bernard Perbal

bperbal@gmail.com

1 Marseille, France promote free access to knowledge and led me, and the entire editorial board of CCS, to present our resignation in $2007 .{ }^{1}$

The continuation of our journal was made possible with a slightly different name in order to avoid confusion, and one that would clearly distinguish our new agreement with Springer from our previous relation with BMC. Events could have taken another turn today with the present merger of BMC and Springer.

In any event, the Journal of Cell Communication and Signaling (JCCS) was born in 2007 and became the official journal of the International CCN Society that I had created in 2001.

From its inception, JCCS has published manuscripts discussing intercellular and intracellular signaling pathways that underlie the interactions of cells with each other and with the surrounding environment. Along this line we have gradually focused our attention on the mechanisms of how cells cross-talk with their surrounding microenvironment in normal and pathological situations.

Surprisingly, BioMed decided in 2008 to reuse the CCS acronym that I had created, and run the same type of scientific publication with a new editorial board, regardless of the intellectual property rights attached to the use of an acronym that was my personal creation. One unexpected consequence was that CCS took advantage of our investment to grow up a decent IF whereas JCCS had to restart from scratch.

In spite of this unfair competition, the JCCS Impact Factor increased to a 3.9 Impact Factor after a few years of hard work, and is now expected to rapidly exceed this figure.

\section{From protein signaling and cell communication to biology of microenvironment}

JCCS was originally meant to provide a support to the new research field that emerged from the discovery of a new family of six CCN proteins sharing both important and unique

\footnotetext{
1 A more detailed account of the events leading to our decision was
} published in Perbal B (2015) (see references). 
structural features but showing distinct and complementary biological properties in fundamental aspects of normal and pathological cell biology.

The unity of this original field was hampered by personal habits and feelings. It suffered from unproductive competitions that found their roots in the use of various acronyms that not only generated misconceptions and lack of scientific precision, but impeded progress and cooperation.

We have made efforts during each of the international workshops on the CCN family of genes that we have organized over the past 20 years and invited all users of the various acronyms to join in a community that would allow them to physically interact and exchange scientific information from which they would benefit (Perbal and Perbal 2016).

JCCS was a unique opportunity for the CCN field that sparse and isolated groups did not even consider for sharing their knowledge and progress.

With Andrew Leask, who was very supportive of JCCS from the very early days, we quickly realized that there was no point "tilting at windmills" and that the Journal should be open to all fields of research dealing with translational research (Leask and Perbal 2019). Moreover, we should build our publication readership and authorship network on all aspects of cell communication and signaling, going far beyond our initial focus.

Following adjustments that occurred over a few years, we have relied for quite some time on a solid group of editorial board members who represent a wide array of expertise that was recently outlined by them in the frame of a special communication (Perbal 2020a).

Under the scientific incentive of Professor Andrew Leask and with the help of Professor Satoshi Kubota, most of them actively participate in the selection of qualified reviewers and the review process that all manuscripts submitted to JCCS have to comply with.

\section{The future}

After 14 years of loyal service to Springer, as the founder and Editor-in-Chief of the Journal of Cell communication and Signaling, I feel that it is time to delegate the scientific responsibility of our Journal to Professor Andrew Leask whose active contribution as the managing editor of JCCS, over quite a few years, has been instrumental in its success.

It is time to introduce "fresh blood and ideas" in the management of JCCS, and I am convinced that Andrew will do his best to bring in his own views to JCCS on the role that our journal can play in the diffusion of excellent science in the field of cell communication with the microenvironment both in normal and pathological conditions.
I have not doubt that the dedication of Andrew Leask as the Editor in Chief of JCCS will be instrumental for the consolidation of JCCS's position as a recognized international journal in the field of modern cell biology.

As I had previously mentioned at the Niagara meeting in November 2019, I have started with the help of Annick Perbal, in the first semester of 2020, a rejuvenation of the International CCN Society by creating a sister scientific society (ARBIOCOM) whose aim is to co-ordinate interactions among a group of various societies that are united by a common interest in cell signaling and communication at large.

This project should result in a more effective, interactive communication among scientific societies working in our fields including medical and pharmaceutical groups.

In any case, Annick and I will keep in very close contact with the managing editors at Springer in the course of our non-profit societies duties.

As of today, the first ARBIOCOM international meeting is scheduled for April 2021 at the same time as the $11^{\text {th }}$ workshop on the $\mathrm{CCN}$ family of genes, if global safety and health conditions permit.

It is now time for me to deeply thank Andrew, Satoshi and Annick for their great help and daily managing support, all my colleagues who participated in the JCCS venture, the authors who chose JCCS to publish their work and our readers, Peter Butler for introducing me to the Springer world, all the active members of the JCCS editorial board for their outstanding participation, Dr.William Curtiss and Dr. Alison Mitchell for their understanding and support, all the members, past and new, of the Springer staff who shared my satisfactions and pains of running JCCS, and all those who like my dear friend Dr. Herman Yeger expressed their constant support behind the scenes.

The JCCS experience with Springer publishing was a great source of profound joy and excitement.

Thank you all.

Bernard Perbal,

January 1, 2021.

\section{References}

Joliot V, Martinerie C, Dambrine G, Plassiart G, Brisac M, Crochet J, Perbal B (1992) Proviral rearrangements and overexpression of a new cellular gene (nov) in myeloblastosis-associated virus type 1-induced nephroblastomas. Mol Cell Biol 12(1):10-21. https:// doi.org/10.1128/mcb.12.1.10 
Leask A, Perbal B (2019) JCCS- A journal for translational research. J Cell Commun Signal 4(3):113. https://doi.org/10.1007/s1207 9-010-0094-y

Leask A, Perbal B (2020) Report on the 10th international workshop on the CCN family of genes October 21-24, 2019, Niagara Falls, Canada. J Cell Commun Signal 14(3):267-269. https://doi. org/10.1007/s 12079-020-00577-0

Perbal B (2003) Communication is the key. Cell Commun Signal 1:3

Perbal B (2015) What kind of a life for a scientific journal? J Cell Commun Signal 9(3):201-206. https://doi.org/10.1007/s1207 9-015-0306-6

Perbal B (2020a) JCCS editorial board: a wide array of expertise. J Cell Commun Signal 14(1):5-17. https://doi.org/10.1007/s1207 9-020-00561-8
Perbal A (2020b) 10th international workshop on the CCN family of genes, Niagara Falls, Canada, October 21-24, 2019 J Cell Commun Signal. 2020 Sep; 14(3): 271-281. https://doi.org/10.1007/ s12079-020-00578-z

Perbal A, Perbal B (2016) The CCN family of proteins: a 25th anniversary picture. J Cell Commun Signal 10(3):177-190. https://doi. org/10.1007/s12079-016-0340-z

Perbal B, Tweedie S, Bruford E (2018) The official unified nomenclature adopted by the HGNC calls for the use of the acronyms, CCN1-6, and discontinuation in the use of CYR61, CTGF, NOV and WISP 1-3 respectively. J Cell Commun Signal 12(4):625629. https://doi.org/10.1007/s12079-018-0491-1 